\title{
カレントミラー回路を用いた多端子対ジャイレータの実現
}

\author{
非会員 洼田 謙一（広島工業大学） \\ 会員 沖根 光夫 (広島工業大学)
}

\section{A Realization of Multi-Port Gyrator Using Current Mirror Circuits}

Kenichi Kubota, Non Member, Mitsuo Okine, Member (Hiroshima Institute of Technology)

A current-mode signal processing circuit is quite attractive from low supply voltage operation and high frequency application. A current-mode continuous time filters consist of simple bipolar current mirrors and capacitors and are quite suitable for monolithic integration.

In this paper, we proposed a design of multi-port gyrator using current mirror circuits. Using the multi-port gyrator and capacitors, we can simulate the passive LC filters. The tuning of the filter frequency can be achieved by adjusting the current of a single DC current source.

As examples, third-order and fifth-order lowpass filters are designed for frequencies of $20 \mathrm{MHz}$ to $80 \mathrm{MHz}$. SPICE simulation results are shown to demonstrate the effectiveness of the proposed method.

キーワード : 電流モード,カレントミラー,ジャイレータ, 連続時間系フィル夕

\section{1.まえがき}

近年,連続時間采フィルタにおいて従来の電王モード に対し電流モードで動作する回路は高速化や低電压化が 期待できることから種々検討されている(1) (4).この電流 モードによる回路に使用される能動素子としてはカレン トミラー,電流ホロワ,電流増偪器等があり,高速且つ低電 圧で動作する回路が提案されているこれらの能動素子 の中でカレントミラー回路はより単位的でィル夕の構 成に適用した場合，回路規模が小さくなる.文献(5)の論文 ではバイポーラトランジスタを使用したカレントミラー 回路による積分器を用いてリープフロッグ形フィル夕を 提案している.この回路はトランジスタとコンデンサの みで構成され、フィル夕の遮断周波数も外部の直流電流 源の值を調整することによって簡単に可変できる特徴を 有している.

所で,リープフロッグ形回路に代表される LC シミュ レーション法によるフィルタの構成は LC フィルタの設 計デー夕がそのまま活用できるとともに低素子感度性を 受け継いでいる，LCシミュレーション法の他の手法と してジャイレータとコンデンサを用いてインダクタンス をシミュレートして置き換えるジャイレーターCフィル 夕があるが低域フィルタの様に非接地のインダクタン スを多数要求する場合は多端子対ジャイレー夕の使用が 有利となる(6)（五，また，ジャイレータの他の応用として定 抵抗全域通過回路が簡単に構成できることも示されてい る

そこで、本論文ではカレントミラー回路を用いてジャ
イレーションコンダクタンスが DC 電流源の調整で可変 できる多端子対ジャイレータを提案している、そして、シ ヤイレーターCフィルタに適用して動作の確認を行って いる、まず,カレントミラー回路で入力抵抗を有する電流 制御電流源(CCCS)を実現し，この回路を使用して電圧制 御電流源(VCCS)を構成，そして多端子对ジャイレータに 適用している、ジイレーションコンダタタンスは $\operatorname{CCCS}$ の入力コンダクタンスとなる.ジャイレーターC フィルタとしては,非接地のインダクタンスが必要な低 域フィルタについて示している.両終端抵抗型 LC フィ ルタをシミュレートすることに上り回路内の DC 電流源 は 1 個となり,この值の調整で可変つィル夕特性が得ら れる。

適用例亡して,3 次有極形低域フィルタと 5 次バター ワース形低域フィル夕を設計し,基準化周波数を $20[\mathrm{MHz}]$ から $80[\mathrm{MHz}]$ まで可変させた場合のフィルタ 特性をSPICE を用いてシミュレートしている

\section{2. カレントミラーを用いたVCCS}

バイポーラトランジスタを用いて人力抵抗を有する2 出力 CCCS を図 1 に示す図 1(a).(b)は土1 倍の利得を有 する回路で同図(c),(d)は+1倍の 2 出力タイプである

トランジスタのßを理想値すなわち無限大と仮定する 亡入力抵抗 $\mathrm{G}^{-1}$ は

$$
\mathrm{G}^{-1}=\frac{0.0259}{\mathrm{I}_{\mathrm{b}}}
$$


で与えられ，直流電流源 $I_{\mathrm{b}}$ を変化させることで $\mathrm{G}^{-1}$ の值 を変化させることができる

図1の回路はトランジスタとDC 電流源のみで実現さ れており集積回路でのトランジス夕間の整合性を利用し た構成となっている。

図1の CCCS を用いて VCCS を実現する回路を図 2 に示す図 2 (a)が VCCS の等価回路である、すなわち, 利 得 +1 の出力端子から帰還をかけることにより入力イン ピーダンスを無限大としている。

\section{3. 多数子対ジ+イレータ}

3.12 端子対ジャイレータ

前章の VCCS を用いて 2 端子対ジャイレー夕を構成 する回路を図 3 に示している.この回路の Y一行列は

$$
\left[\begin{array}{l}
I_{1} \\
I_{2}
\end{array}\right]=\left[\begin{array}{cc}
0 & -G \\
+G & 0
\end{array}\right]\left[\begin{array}{l}
V_{1} \\
V_{2}
\end{array}\right]
$$

で与えられる

3.23 端子対ジャイレータ

次に,3端子対ジャイレータのYー行列は

$$
\left[\begin{array}{l}
I_{1} \\
I_{2} \\
I_{3}
\end{array}\right]=\left[\begin{array}{ccc}
0 & -G & 0 \\
+G & 0 & -G \\
0 & +G & 0
\end{array}\right]\left[\begin{array}{l}
V_{1} \\
V_{2} \\
V_{3}
\end{array}\right]
$$

で与えられ,CCCS のシンボル図を用いた構成回路を図 4 (a),その実現回路を同図(b)に示している

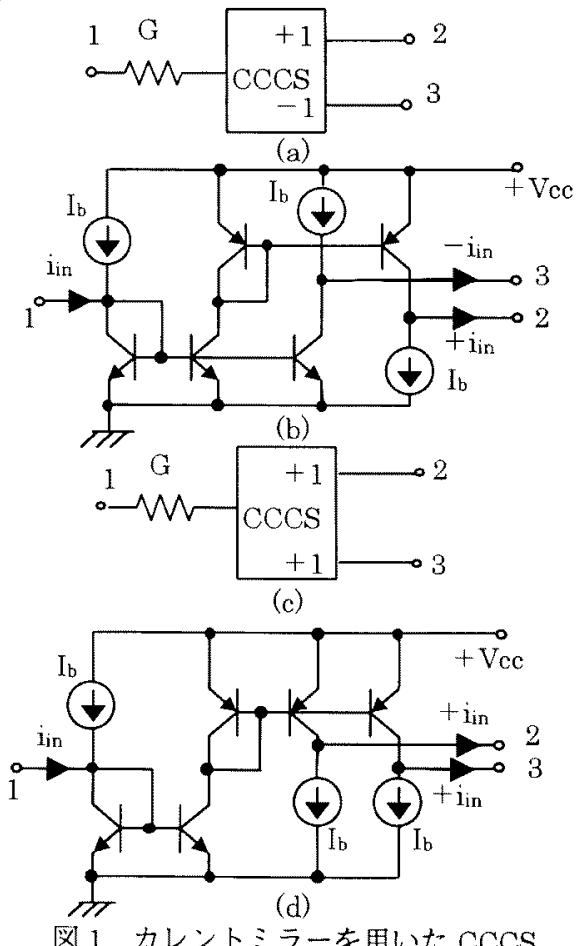

図 1 カレントミラーを用いた CCCS

Fig.1. CCCS using current mirrors

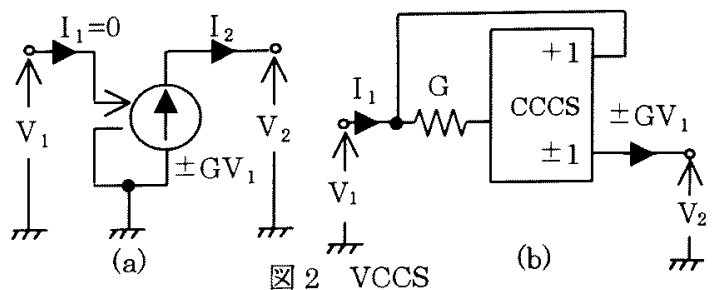

Fig.2. VCCS

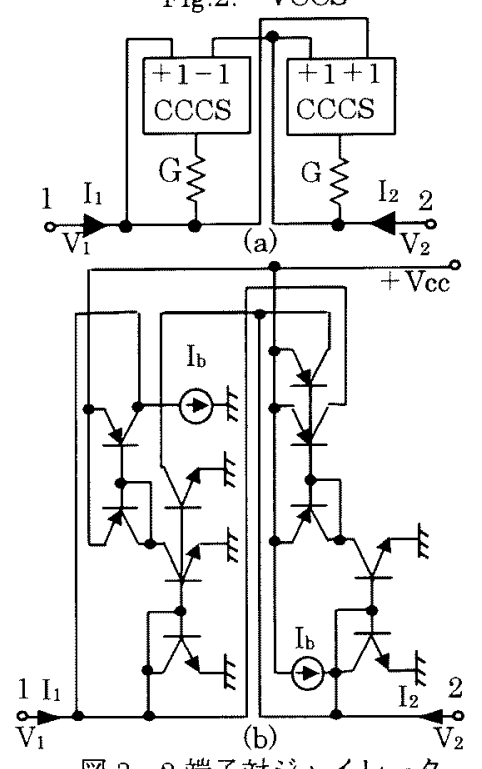

図 32 端子対ジャイレータ

Fig.3. 2-port gyrator
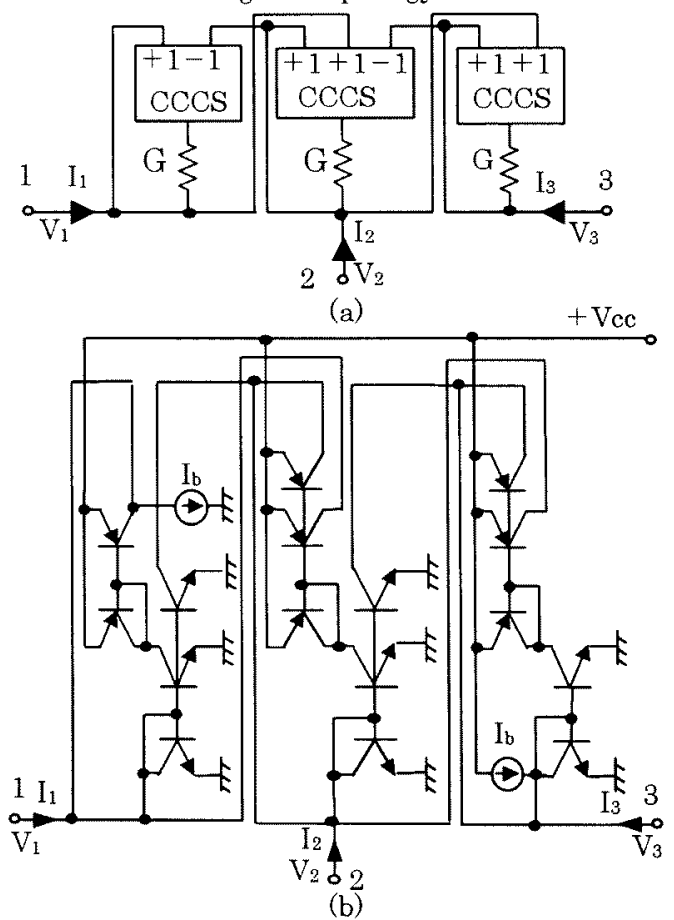

図43 端子対ジャイレータ

Fig.4. 3-port gyrator 
$3.3 \mathrm{n}$ 端子対ジャイレータ

この 3 端子対ジャイレータを $\mathrm{n}$ 端子対ジャイレータ に抎張した回路が図 5 となるここ回路の Y - 行列は

$$
\left[\begin{array}{c}
I_{1} \\
I_{2} \\
I_{3} \\
\vdots \\
\vdots \\
I_{n-1} \\
I_{n}
\end{array}\right]=\left[\begin{array}{ccccccc}
0 & -G & 0 & 0 & \cdots & 0 & 0 \\
+G & 0 & -G & 0 & \cdots & 0 & 0 \\
0 & +G & 0 & -G & \cdots & 0 & 0 \\
& \cdots & \cdots & \cdots & \cdots & \cdots & \\
0 & 0 & \cdots & 0 & 0 & -G & 0 \\
0 & 0 & \cdots & 0 & +G & 0 & -G \\
0 & 0 & \cdots & 0 & 0 & +G & 0
\end{array}\right]\left[\begin{array}{c}
V_{1} \\
V_{2} \\
V_{3} \\
\vdots \\
\vdots \\
V_{n-1} \\
V_{n}
\end{array}\right](4)
$$

となり，端子 2 から $\mathrm{n}-1$ までは 3 出力の CCCSを使用 することになる.ジャイレーションコンダクタンスの值 在決定する DC 電流源 $\mathrm{I}_{\mathrm{b}}$ は 2 個回路中に存在する。

\section{4. ジャイレーターCフィルタ}

LC 低域フィルタに必要なインダクタンスは図 6(a)に 示す様な非接地の L が接続された形のものとなり、この 回路は同図(b)に示す様に多端子対ジャイレータを用い て簡単にシミュレートすることができるすすなお，偶数 端子と接地間に接続したコンデンサが等価的に奇数端子 間に現れる.各インダクタンスの值は

$$
\mathrm{L}_{2 \mathrm{j}}=\mathrm{C}_{2 \mathrm{j}} / \mathrm{G}^{2} \quad\left(1 \leq \mathrm{j} \leq \frac{\mathrm{n}-1}{2}\right)
$$

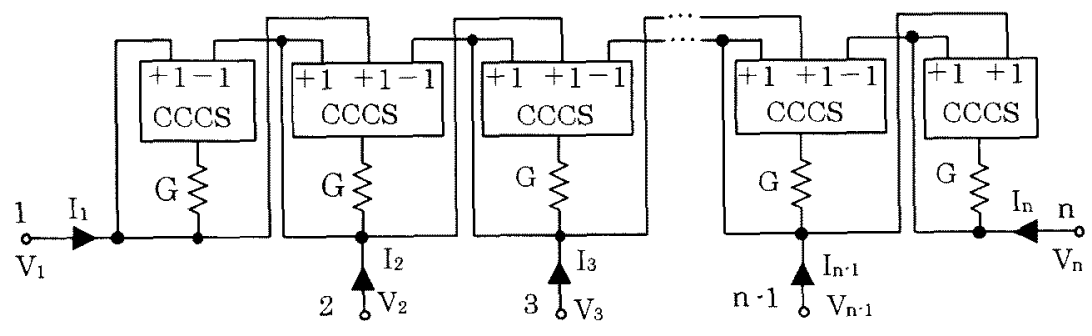

(a)

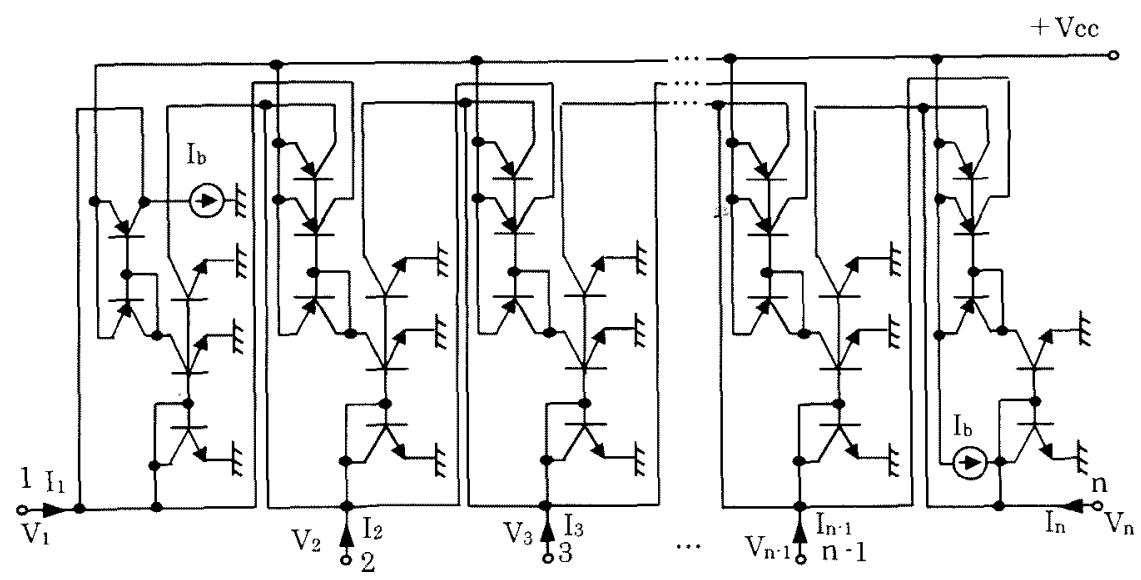

(b)

因 5 n端子対ジャイレータ

Fig.5. n-port gyrator 

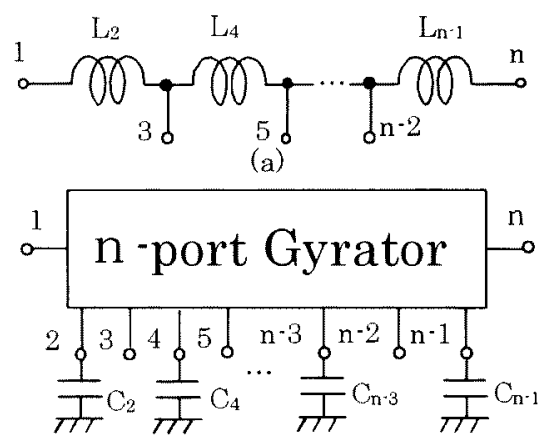

(b)

図 6 非接地形インダクタンス

Fig.6. Floating inductance となるここ非接地インダタタンスを用いて $\mathrm{n}$ 次低域フ イル夕を実現する回路を図 7 に示している.両終端の抵 抗 $\mathrm{G}$ をトランジスタで置き換え, $\mathrm{DC}$ 電流源 $\mathrm{Ib}$ をまめ ると図 7 (b)に示す様に $2 \mathrm{I}$ 犆を持つ一個の電流源之 することができる.勿論,電流源 $2 \mathrm{Ib}$ を変化させることに より,フィルタの遮断周波数が変化する可変フィルタ特 性が得られるこのことはコンデンサの絶対精度による 特性のズレを簡単に $2 \mathrm{Ib}$ の調整により補正することがで きることにもなる、有極形は，等価インダクタンスに並列 に容量を接続することによって得られる

なお，図 7(b)の回路の入力部之出力部を変形すると文 献(5)のリープフロッグ形回路が導出できる

\section{5. 輝成例とシミュレーション結果}

構成例亡して，3 次有極形低域フィルタと 5 次バ夕ー ワース形低域フィル夕を多端子対ジャイレータを用いて 央現した. そして,SPICE によるシミュレーションは主要 なパラメータとして

$\mathrm{f}_{\mathrm{T}}=5[\mathrm{GHz}], \quad \beta=80$ の npn トランジスタ

$\mathrm{f}_{\mathrm{T}}=1[\mathrm{GHz}], \quad \beta=50$ onp トランジスタ

を用いて行なった。おお,フィル夕特性は基準化周波数

$\mathrm{f}_{0}$ を $20,40,60,80[\mathrm{MHz}]$ となる様, $2 \mathrm{I}_{\mathrm{b}}$ を調整して調へた。

\subsection{3 次有極形低域フィル夕}

3 次有極形 LC 低域フィルタを図 8(a)に示す. 通過域は リップルが 0.18[dB]，減衰域の最小減衰量が 25.6[dB]の 特性を実現する回路としている.図8(b)がそのシミュレ 一ト回路である. 回路パラメータは表 1 に示してお り, $2 I_{6}$ については調整後の值を示している.

表 1 設計值 (3 次)

Table 1. Designed values(Third-order)

\begin{tabular}{|c|c|c|c|c|}
\hline $\mathrm{f}_{0}[\mathrm{MHz}]$ & $2 \mathrm{I}_{\mathrm{b}}[\mu \mathrm{A}]$ & $\mathrm{C}_{1}=\mathrm{C}_{3}[\mathrm{pF}]$ & $\mathrm{C}_{2}[\mathrm{pF}]$ & $\mathrm{C}_{2}^{\prime}[\mathrm{pF}]$ \\
\hline 20 & 148 & & & \\
\cline { 1 - 2 } 400 & 300 & \multirow{2}{*}{20.0} & \multirow{2}{*}{18.0} & 4.2 \\
\cline { 1 - 2 } 60 & 450 & & & \\
\hline 80 & 603 & & & \\
\hline
\end{tabular}

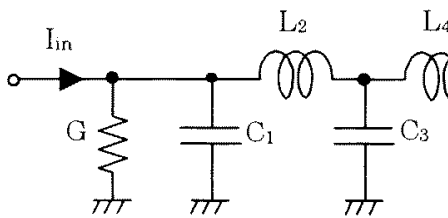

$\mathrm{L}_{4} \quad \mathrm{~L}_{6}$

$\mathrm{L}_{6} \quad \mathrm{~L}_{\mathrm{N}} \cdot 1$

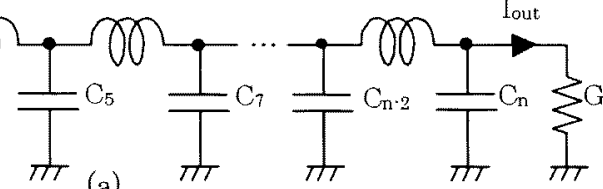

(a)
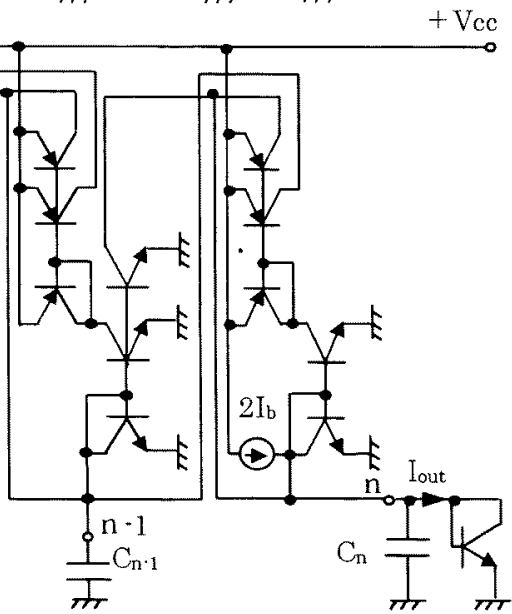

(b)

図 7 低域フィルタ

Fig.7. Lowpass filter 


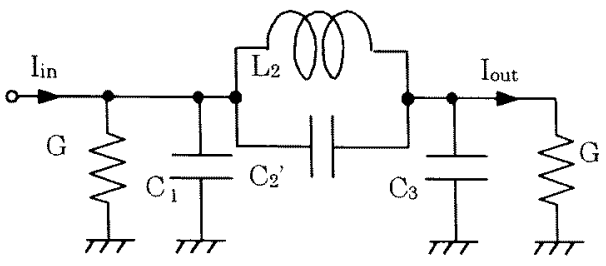

(a)

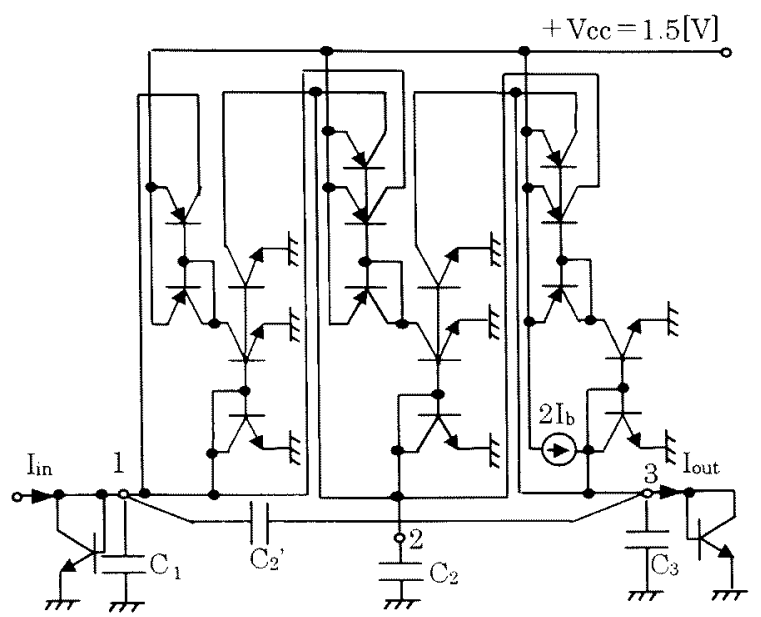

(b)

图 83 次有極形低域フィルタ

Fig.8. Third-order lowpass filter with finite zero

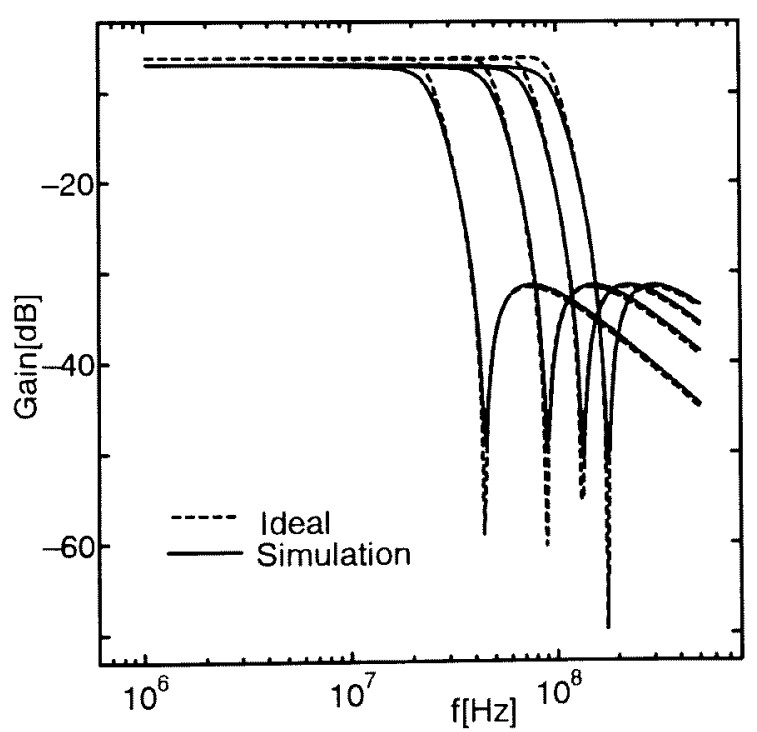

図 9 シミュレーション結果(3次)

Fig.9. Simulation results(Third-order)
シミュレーション結果を図 9 に示している.フィル夕特 性のゲインが䄪 $0.8[\mathrm{~dB}]$ 低下しているのみではぼ良好な 結果が得られているにのゲインの低下はカレントミラ 一回路の土1 倍のゲインが若下低下している理由による また,奇生容量によるフィル夕特性の影響を考えると、ま ず非接地の $\mathrm{C}_{2}$ のボトムプレート側の蓉量は $\mathrm{C}_{1}$ あるい は $\mathrm{C}$ の 20[pF]に対して並列接続されることとなるが小 容量のため殆ど影響は受けない、一方けランジス夕の獉

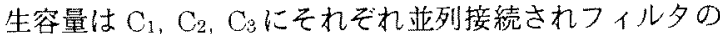
特性は周波数軸にそって茟かではあるが平行移動する。 このズレは $2 \mathrm{I}_{\mathrm{b}}$ で簡単に調整できる。

な拉,THD は各 $f_{0}$ に招いて, 入力電流を $5[\mu \mathrm{A}]$ ステッ

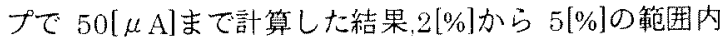
の值を取った

\section{2 無極形 5 次 LPF}

5 次 LC フィルタを図 10(a)に示し，そのシミュレート 回路を同図(b)に示している.各回路パラメータを表 2 に 記している.シミュレーション結果を図 11 に示している が、ぼ良好な結果が得られており，THDについても各 $\mathrm{f}_{0}$ で入力電流 $50[\mu \mathrm{A}]$ まで $5[\%]$ 以内の值となった.レベ ルの低下は約 $1.1[\mathrm{~dB}]$ となっている

なお,3 次有極形フィル夕と同様に文献(5)の面積調整と 寄生容量を考虑した設計は行わないでシミュレートして いる。

L2 $\quad \mathrm{L}_{4}$

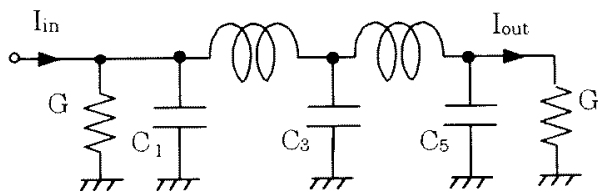

(a)

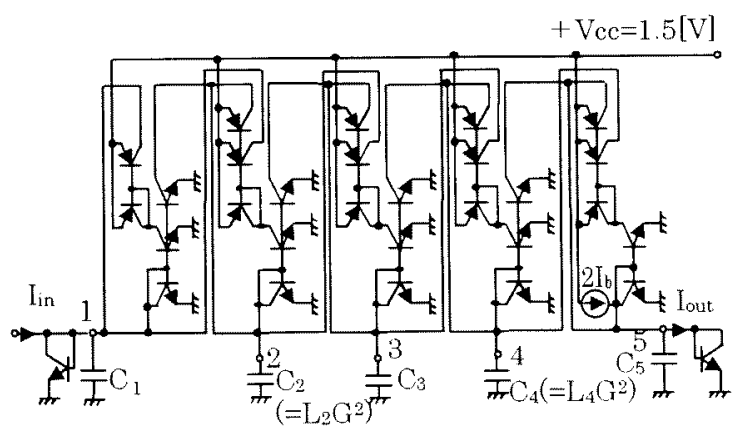

(b)

図 105 次低域フィルタ

Fig.10. Fifth-order lowpass filter 
表 2 設計值 $(5$ 次)

Table 2. Designed values(Fifth-order)

\begin{tabular}{|c|c|c|c|c|}
\hline $\mathrm{f}_{0}[\mathrm{HHz}]$ & $2 \mathrm{I}_{\mathrm{b}}[\mu \mathrm{A}]$ & $\mathrm{C}_{1}=\mathrm{C}_{5}[\mathrm{pF}]$ & $\mathrm{C}_{3}[\mathrm{pF}]$ & $\mathrm{C}_{2}=\mathrm{C}_{4}[\mathrm{pF}]$ \\
\hline 20 & 85 & & & \\
\cline { 1 - 2 } 40 & 170 & \multirow{2}{*}{6.2} & \multirow{2}{*}{20.0} & \multirow{2}{*}{16.2} \\
\cline { 1 - 2 } 60 & 260 & & & \\
\cline { 1 - 2 } 80 & 350 & & & \\
\hline
\end{tabular}

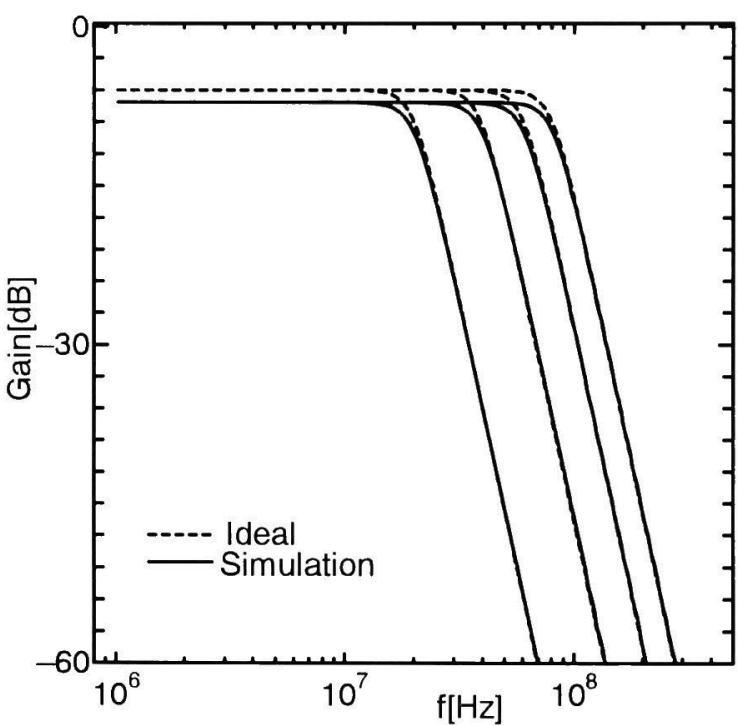

図 11 シミュレーション結果(5 次)

Fig.11. Simulation results(Fifth-order)

\section{6. むすひ}

カレントミラー回路を用いて VCCS を構成し,多端子 対ジャイレータの実現に適用した.ジャイレーションコ ンダクタンスは DC 電流源の值によって容易に調整でき る特街を有しているこのことはジャイレーターC フィ ル夕や定抵抗全域通過回路を提案の多端子対ジャイレー 夕を用いて構成した場合,コンデンサの絶対值偏差によ る特性のズレが補正できること,さらに可変フィル夕特 性が実現できることになる，

そして,構成した多端子対ジャイレータの動作確認の ため, 3 次有極形亡 5 次バターワース形低域フィル夕に ついて基準化周波数 $\mathrm{f}_{0}$ を $20[\mathrm{MHz}]$ から $80[\mathrm{MHz}]$ まで 可変したフィル夕特性を SPICE を用いて調べた.両者之 もカレントミラー回路におけるゲインの低下を補うため のトランジスタのエミッタ面積の調整と寄生容量分によ るコンデンサの值の補正は行わない回路をシミュレート した.その結果,フィルタのゲインが若干低下するのみで ほぼ良好なフィル夕特性が得られたしかし,各 foでの THD が入力電流 $50[\mu \mathrm{A}]$ まで $2[\%]$ から $5[\%]$ の範囲内の
值を取りここの低減が今後の検討課題として残されてい る.

\section{蝴辞}

本研究を進めるにあたり,有益なご指導ご助言を頂い た東京工業大学藤井信生教授, 高木茂孝助教授に深く感 謝いたします。

(平成 12 年 5 月 15 日受付,平成 12 年 11 月 30 日再受付)

\section{文就}

(1) R.Angulo,M.Robinson, and E.S.Sinencio, “Current mode continuous-time filters: two design approaches," IEEE Trans.Circuits Systs., Vol.39.No.5, pp.337-341, June.1992.

(2) S.S.Lee,R.H.Zele,D.J.Allstot and G.Liang, "CMOS continuous-time current-mode filters for highfrequency applications," IEEE J.Solid State Circuits, Vol.28,No.3,pp.323-329,March.1993.

（3）永作俊幸,兵庫明,関根慶太郎, “低電圧で動作可能な力 レントアンプとその応用, $"$ 電気学会研究会資料,ECT 95-30,1995.

（4）永作俊幸, 兵庫明,関根慶太郎, “利得可変な電流モード 増幅器とその応用," 電気学会研究会資料,ECT-96-44, 1996

(5) J.C.Ahn and N.Fujii, "Current-mode continuoustime filters using complementary current mirror pairs," IEICE Trans.Vol.E79-A,No.2,pp.168-175, Feb.1996.

（6）沖根光夫,石川弘文,中村正孝: “多端子対ジャイレー夕 の構成之伝送回路網への応用”，信学論(A),J57-A,6,pp 467-473(1974-06).

（7）石井幸男: “多端子対ジャイレータの一構成方法”, 信 学論(A),J62-A,8,pp.533-534(1979-08).

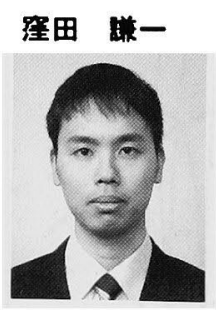

（非会員） 1978 年 3 月 8 日生. 2000 年 3 月広島工業大学工学部電気工学科卒業 同年 4 月広島工業大学大学院博士前期課 程電子工学専攻在学中.電子情報通信学 会会員.

沖根 光夫

（正員） 1947 年 3 月 6 日生. 1969 年 3

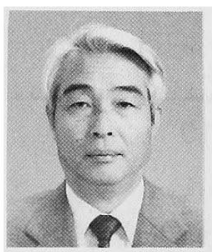
月広島工業大学工学部電子工学科卒業 同年 4 月広島工業大学工学部電気工学 科勤務現在同大学電気・ディジタルシス テム工学科教授、電子回路,アナログ信号 処理回路に関する研究に従事. 電気学会 電子情報通信学会会員. 